\author{
Robert Cichowicz, Artur Stelegowski \\ Lodz University of Technology, Faculty of Architecture, Civil and Environmental Engineering \\ al. Politechniki 6, 90-924 Lodz, Poland, robert.cichowicz@p.lodz.pl, arturstelegowski@gmail.com
}

\title{
SELECTED AIR POLLUTANTS IN URBAN AND RURAL AREAS, UNDER THE INFLUENCE OF POWER PLANTS
}

\begin{abstract}
The operation of large power plants, including power stations, and combined heat and power stations, causes the emission of significant amounts of gaseous pollutants into the environment. As a result, in the urban and agricultural areas occurs a pollution of undesirable gaseous substances, such as nitrogen and sulfur oxides. This is especially dangerous for living organisms, soil and water, because, in combination with water vapor, these pollutants are the cause of acid rain. In addition, nitrogen oxides participate in the formation of ground-level ozone, which affects both human health and the condition of existing vegetation. Therefore, the distribution of air pollutants $\left(\mathrm{NO}_{2}, \mathrm{SO}_{2}\right.$ and $\left.\mathrm{O}_{3}\right)$ in the selected urban and rural areas, under the influence of power plants, located in the Lodz Voivodeship, in Poland, in Central-Eastern Europe, was analyzed for a 10-year period (2007-2016). As a result, it was possible to evaluate the impact of the entry into force of Directive 2008/50/EC of the European Parliament and of the Council of 21 May 2008 "on ambient air quality and cleaner air for Europe" on the changes in emissions and concentrations of pollutants in selected locations. As a result of the analysis, a significant decrease in the concentration of $\mathrm{SO}_{2}$ (by $75 \%$ in the urban area and by $59 \%$ in the rural area), and small changes (from - $8 \%$ to $+12 \%$ ) in $\mathrm{NO}_{2}$ and $\mathrm{O}_{3}$ concentrations in ambient air were found. This indicates the effectiveness of actions aimed at reducing $\mathrm{SO}_{2}$ emissions, however the influence of the power plants on the concentration of air pollutants in these areas is not clear. At the same time, considering the criterion of permissible concentration of ozone and nitrogen dioxide, although the air quality did not improve, the air quality index can be considered as being in the category of "good".
\end{abstract}

\section{Key words}

air pollution; rural area; urban area; power plants

\section{Introduction}

Production of heat and electricity for broadly understood "urban and village goals" is currently mainly based on large power stations. They can operate based on alternative/renewable sources or fossil fuels. As a result of fossil fuel combustion, significant amounts of pollutants, including gas pollutants, enter the environment [1]. And the presence of undesirable substances in the fuel, as well as the efficiency of air pollution control devices, determines, among others, the amount of nitrogen and sulfur oxides emitted into the atmosphere. Consequently, elevated concentrations of nitrogen and sulfur oxides in the air negatively affect human health and the environment [2-4]. This causes problems with the respiratory system (asthma) [2,5-6], the formation of acid rain [7] and reduced crop yield [8]. In addition, nitrogen oxides contribute to the formation of harmful to humans ground-level ozone [7,9]. Therefore, the emissions from point sources of power plants can be decisive in the total share of pollutant emissions in a given area, e.g. of a city, a voivodeship or a country [10].

Depending on the location and height of the emitter, air pollutants may enter areas with different terrain characteristics, population density and vegetation occurrence. Urban areas generally have high density of buildings, which is associated with a high population density and small vegetation area. Large share in air pollution have areal and linear sources, and air quality is often considered to be low there, negatively affecting human health [11-12] and therefore requiring improvement [13-14]. At the same time, significant amounts of air pollutants are emitted from industrial boiler plants and power stations, as well as combined heat and power plants, located in the city [15]. In agricultural areas, characterized by low density of buildings, low population density and large vegetation area, there is a lower concentration of pollutants from vehicle traffic and individual heating systems, which means that the quality of air in these areas is considered to be cleaner and therefore "better" $[12,16]$. However, the emission from point sources of power stations may have a major impact on the concentration of air pollutants in these areas [17-18].

As the importance of these issues and in order to protect human health and the environment, the European Parliament and the Council introduced Directive 2008/50/EC of 21 May 2008 "on ambient air quality and 
cleaner air for Europe" (the so-called CAFE Directive) [19]. Its detailed objective is, among others, taking actions aimed at identifying and reducing emissions of air pollution at source and establishing appropriate air quality objectives, taking into account, inter alia, World Human Organization recommendations and programs. According to the CAFE Directive [19], the "air quality status should be maintained where it is already good, or improved " and "Member States should take action in order to comply with the limit values and critical levels, and where possible, to attain the target values and long-term objectives". In addition to protecting human health, the Directive [19] focuses on the protection of vegetation and for this reason the assessment of air quality should be carried out not only in urban agglomerations (urban areas), where the concentration of pollutants often exceeds the target values, but also far from built-up areas, so on agricultural (rural) areas. In order to achieve the objectives of cleaner air for Europe, measures have been established to obtain and provide information as well as assess air quality and promote cooperation between European Union Member States in reducing air pollution.

In addition, due to the significant emission of air pollutants from large combustion plants, Directive of the European Parliament and of the Council 2010/75/EU of 24 November 2010 "on industrial emissions (integrated pollution prevention and control)"[20] was introduced, specifying the limits of industrial emissions (including emissions from power plants). The efforts to improve air quality were reflected in the legislation of the European Union Member States, and therefore in Poland the Environmental Protection Law [21] and related regulations [22] were amended, and national and local air protection programs were established [23].

In Poland, in order to identify, assess and plan the improvement of air quality, the air quality monitoring is carried out, inter alia by the Provincial Environmental Protection Inspectorates. Collection of data on air quality is carried out using measuring stations, both manual and automatic or mixed automatic-manual. As the criteria for air quality assessment, the values given by the WHO guidance [2,24] and by the Directive 2008/50/EC [19] are used as the recommended concentration of air pollutants, i.e. the maximum level of air pollution with no adverse effects on human health.

Since the impact on concentration of air pollutants in areas which vary in terms of urban planning, is made, among others, by point sources of combustion plants, e.g. local power plants and combined heat and power plants [23], therefore the following article analyzes the distribution of air pollutants in the selected urban and agricultural area in the Lodz Voivodeship, Poland, in the Central and Eastern Europe. As a result, the effect of emissions from point sources of large power stations on the concentration levels of selected pollutants in atmospheric air in a period of 10 consecutive years (2007-2016) was observed and analyzed.

\section{Method description}

The distribution of selected air pollutants has been analyzed based on data from measurement stations located: one in the city ("Lodz-Widzew") and the second in the agricultural/rural area ("Parzniewice"), in the Lodz Voivodeship, Poland, in Central and Eastern Europe, influenced by power plants in the last decade (years 2007-2016). The concentrations of $\mathrm{NO}_{2}, \mathrm{SO}_{2}$ and $\mathrm{O}_{3}$ were analyzed, the measurements of which were carried out automatically in a continuous (hourly) mode at measurement stations that subject to the Provincial Environmental Protection Inspectorate in Lodz.

The measurement station "Lodz-Widzew" (fig. 1) is located at Czernika Street 1/3 in Lodz, in the urban area of low density residential (towards north, south and west) and the park (towards east) [25]. Lodz is a city with poviat rights, with a population of over 500,000 inhabitants and a population density of approximately 2390 people $/ \mathrm{km}^{2}$. The geographical coordinates of the position of the measuring station are $\mathrm{N} 51^{\circ} 45^{\prime} 28.98^{\prime \prime}$, E19 $31^{\prime} 47.23^{\prime \prime}$. The measuring station is located approximately $1.4 \mathrm{~km}$ from the "EC-4" combined heat and power plant (with an electricity capacity about $198 \mathrm{MW}$ and thermal power of approximately $820 \mathrm{MW}$, fueled with hard coal and biomass) and located at Andrzejewska Street 5 in Lodz (fig. 1). The "EC-4" power plant is one of two operating power plants in Lodz city and it belongs to the Veolia Energia Lodz SA (formerly Dalkia Lodz SA) company. The representativeness of the results of the "Lodz-Widzew" measurement station is several kilometers, which coincides with the number of about 10,000 inhabitants. 


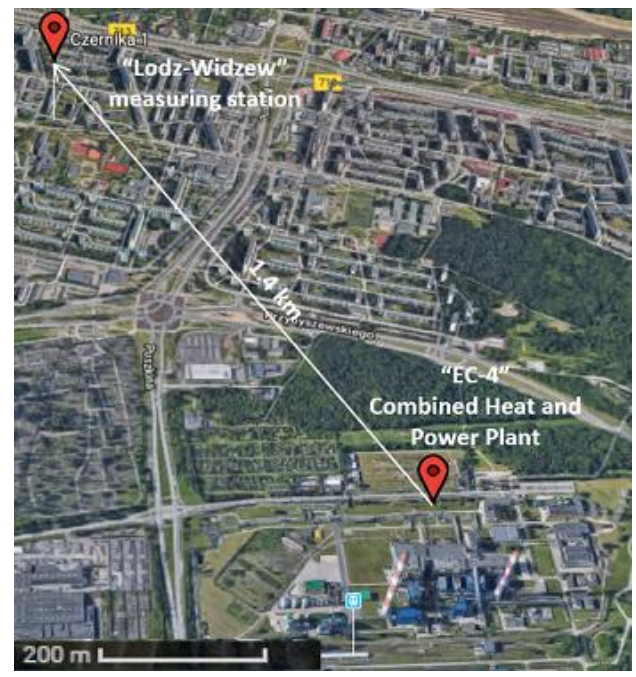

Fig. 1. The "Lodz-Widzew" measuring station and "EC-4" power plant Source: [26]

The "Lodz-Widzew" measuring station is equipped with $\mathrm{PM}_{2.5}, \mathrm{PM}_{10}, \mathrm{NO}, \mathrm{NO}_{2}, \mathrm{SO}_{2}, \mathrm{CO}$ and $\mathrm{O}_{3}$ analyzers (table 1).

Table 1. Equipment of "Lodz-Widzew" measuring station

\begin{tabular}{|l|l|l|}
\hline Device type & Air pollutant type & Measuring method \\
\hline BAM 1020 & $\mathrm{PM}_{2.5}$ & $\begin{array}{l}\text { attenuation of the beta ray; } \\
\text { detection threshold }<4.0 \mu \mathrm{g} / \mathrm{m}^{3}(1 \mathrm{~h})\end{array}$ \\
\hline Thermo 42i & $\mathrm{NO}, \mathrm{NO}_{2}$ & $\begin{array}{l}\text { chemiluminescent technology; } \\
\text { detection threshold } 50 \mathrm{ppb}\end{array}$ \\
\hline Thermo 43i & $\mathrm{SO}_{2}$ & $\begin{array}{l}\text { pulsed fluorescence technology; } \\
\text { detection threshold } 50 \mathrm{ppb}\end{array}$ \\
\hline Thermo 48i & $\mathrm{CO}$ & $\begin{array}{l}\text { absorbance of infrared radiation; } \\
\text { detection threshold } 1 \mathrm{ppm}\end{array}$ \\
\hline Thermo 49i & $\mathrm{O}_{3}$ & $\begin{array}{l}\text { UV photometric; } \\
\text { detection threshold } 0.5 \mathrm{ppb}\end{array}$ \\
\hline Thermo 5014i & $\mathrm{PM}_{10}$ & $\begin{array}{l}\text { attenuation of the beta ray; } \\
\text { detection threshold }<4.0 \mu \mathrm{g} / \mathrm{m}^{3}(1 \mathrm{~h})\end{array}$ \\
\hline
\end{tabular}

Source: [25]

The "Parzniewice" measuring station is located in close proximity to Parzniewice village, in agricultural and rural area [27]. Parzniewice is a village with less than 500 inhabitants and is located in the Piotrkow Trybunalski poviat of population density of about 63 people $/ \mathrm{km}^{2}$. The geographical coordinates of the station's location are N 51 ${ }^{\circ} 17^{\prime} 28.23^{\prime \prime}$, E19 $31^{\prime} 03.20^{\prime \prime}$. The station is located about $13 \mathrm{~km}$ from the "PGE GIEK Betchatow" power plant (with an electric power of approximately 5,342 MW, fuel: brown coal), located at Energetyczna Street 7, in Rogowiec near Belchatow city (fig. 2). The representativeness of the measurement station results is several kilometers [27].

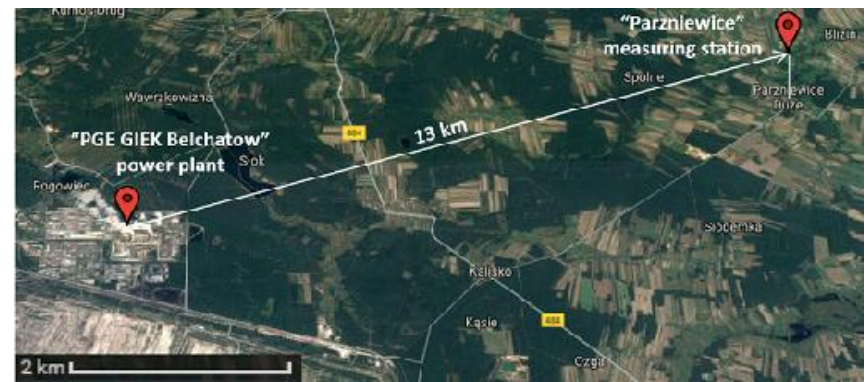

Fig. 2. The "Parzniewice" measuring station and "PGE GIEK Belchatow" power plant Source: [26] 
The "Parzniewice" measuring station is equipped with $\mathrm{NO}, \mathrm{NO}_{2}, \mathrm{SO}_{2}$, and $\mathrm{O}_{3}$ analyzers (table 2).

Table 1. Equipment of "Parzniewice" measuring station

\begin{tabular}{|l|l|l|}
\hline Device type & Air pollutant type & Measuring method \\
\hline Thermo 42i & $\mathrm{NO}, \mathrm{NO}_{2}$ & $\begin{array}{l}\text { chemiluminescent technology; } \\
\text { detection threshold } 50 \mathrm{ppb}\end{array}$ \\
\hline Thermo 43i & $\mathrm{SO}_{2}$ & $\begin{array}{l}\text { pulsed fluorescence technology; } \\
\text { detection threshold } 50 \mathrm{ppb}\end{array}$ \\
\hline Thermo 49i & $\mathrm{O}_{3}$ & $\begin{array}{l}\text { UV photometric; } \\
\text { detection threshold } 0.5 \mathrm{ppb}\end{array}$ \\
\hline
\end{tabular}

Source: [27]

Additionally, for the analysis of emissions and concentrations of air pollutants, the Provincial Environmental Protection Inspectorate reports of the annual air quality assessment in the Lodz Region [23] from 2007 - 2017 were used.

\section{Results}

After analyzing the ten-year data, it can be noticed that the concentration of $\mathrm{NO}_{2}$ is characterized by a slight change of values for the "Lodz-Widzew" and a slight decrease at the "Parzniewice" measurement station. The average annual $\mathrm{NO}_{2}$ concentration ranged from 16.4 to $19.1 \mu \mathrm{g} / \mathrm{m}^{3}$ (average $18.3 \mu \mathrm{g} / \mathrm{m}^{3}$ ) in the first location, and from 12.1 to $15.1 \mu \mathrm{g} / \mathrm{m}^{3}$ (average $13.4 \mu \mathrm{g} / \mathrm{m}^{3}$ ) in the second location, which is significantly below the recommended by WHO average annual value of $40 \mu \mathrm{g} / \mathrm{m}^{3}$ (due to human health protection) and $30 \mu \mathrm{g} / \mathrm{m}^{3}$ (due to vegetation protection) [2]. In the case of the "Lodz-Widzew" measuring station, hourly average $\mathrm{NO}_{2}$ concentrations exceeded $40 \mu \mathrm{g} / \mathrm{m}^{3}$ for 548 hours per year and were no more than $139 \mu \mathrm{g} / \mathrm{m}^{3}$. However, at the "Parzniewice" they exceeded $40 \mu \mathrm{g} / \mathrm{m}^{3}$ for 340 hours per year and were no more than $108.9 \mu \mathrm{g} / \mathrm{m}^{3}$. In summary, in both cases, within 10 years, $\mathrm{NO}_{2}$ concentrations did not exceed the recommended average hourly value of $200 \mu \mathrm{g} / \mathrm{m}^{3}$ (fig 3).

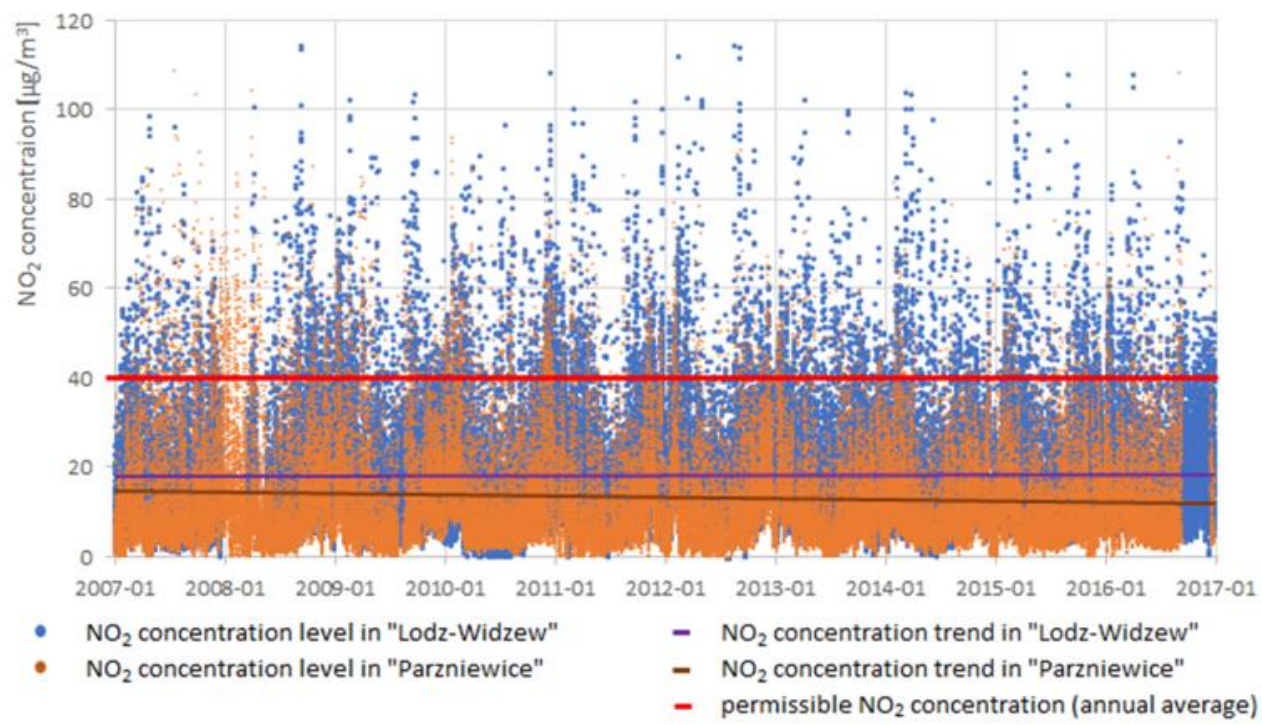

Fig. 3. $\mathrm{NO}_{2}$ concentrations in the selected locations in 2007-2016 Source: Author's

The annual average concentration of $\mathrm{SO}_{2}$ in the air decreased markedly and ranged from 4.0 to $15.8 \mu \mathrm{g} / \mathrm{m}^{3}$ (average $9.9 \mu \mathrm{g} / \mathrm{m}^{3}$ ) in the city, and from 4.0 to $11.5 \mu \mathrm{g} / \mathrm{m}^{3}$ (average $8.6 \mu \mathrm{g} / \mathrm{m}^{3}$ ) in the rural area. Therefore, the $\mathrm{SO}_{2}$ concentrations were significantly below the WHO recommended annual average of $50 \mu \mathrm{g} / \mathrm{m}^{3}$ (due to human health protection) and $30 \mathrm{\mu g} / \mathrm{m}^{3}$ (due to vegetation protection). However, it was observed that the winter season criterion of plant protection (from 1 October to $31 \mathrm{March}$ ) of $20 \mu \mathrm{g} / \mathrm{m}^{3}$ according to the 
Regulation [28], was exceeded in winter 2007/2008 in the urban area. What is more, in the case of the "Lodz-Widzew", the average hourly $\mathrm{SO}_{2}$ concentrations exceeded $50 \mu \mathrm{g} / \mathrm{m}^{3}$ for around 63 hours per year and were no more than $230.4 \mu \mathrm{g} / \mathrm{m}^{3}$. And at the "Parzniewice" measuring station, $\mathrm{SO}_{2}$ concentrations exceeded $50 \mathrm{\mu g} / \mathrm{m}^{3}$ for around 64 hours a year and were no more than $164.6 \mathrm{\mu g} / \mathrm{m}^{3}$. However, within 10 years of measuring the concentration of $\mathrm{SO}_{2}$, there was no exceedance of the recommended average daily value of $125 \mu \mathrm{g} / \mathrm{m}^{3}$ (fig. 4).



Fig. 4. $\mathrm{SO}_{2}$ concentrations in the selected locations in 2007-2016 Source: Author's

As to the ground-level ozone, the $\mathrm{O}_{3}$ average annual concentration in air changed slightly and ranged from 51.1 to $54.7 \mu \mathrm{g} / \mathrm{m}^{3}$ (average $52.8 \mu \mathrm{g} / \mathrm{m}^{3}$ ) in the city, and from 51.6 to $59.8 \mu \mathrm{g} / \mathrm{m}^{3}$ (average $55.8 \mu \mathrm{g} / \mathrm{m}^{3}$ ) in the village. In the case of the "Lodz-Widzew" measuring station, the hourly average $\mathrm{O}_{3}$ concentrations exceeded $120 \mu \mathrm{g} / \mathrm{m}^{3}$ on average for 202 hours per year and were no more than $179.1 \mu \mathrm{g} / \mathrm{m}^{3}$. However, at the "Parzniewice" measuring station, they exceeded $120 \mu \mathrm{g} / \mathrm{m}^{3}$ on average for around 225 hours per year and were no more than $184.7 \mathrm{\mu g} / \mathrm{m}^{3}$ (fig. 5). Also, within 10 years of the $\mathrm{O}_{3}$ concentration measurement, the recommended $\mathrm{O}_{3}$ concentration of $120 \mathrm{\mu g} / \mathrm{m}^{3}$ of 8-hour average was exceeded. In the urban area (represented by the "Lodz-Widzew" station) it was about 17 exceedances per year, and in the agricultural area (represented by the "Parzniewice" station) about 19. The least number of exceedances occurred in 2009 (8 and 16 respectively), and the highest number of exceedances occurred in 2015 (31 and 30 respectively).



Fig. $5 . \mathrm{O}_{3}$ concentrations in the selected locations in 2007-2016

Source: Author's 
In addition, changes in the concentrations of pollutants in the air were compared with the equivalent emission of Veolia Energia Lodz SA (formerly Dalkia Lodz SA), to which belongs two operating power plants (including "EC-4" power plant) in Lodz city, and with the equivalent emission of PGE GIEK Bełchatow power plant. The decrease in the equivalent emission from power plants was mainly related to the capture of sulfur dioxide. Although in 2016 the $76 \%$ emission reduction by Veolia Energia Lodz SA corresponds to the $75 \%$ reduction of $\mathrm{SO}_{2}$ concentration at the "Lodz-Widzew" measuring station, and similarly the $61 \%$ emission reduction by PGE GIEK Bełchatow corresponds to the $59 \%$ reduction of $\mathrm{SO}_{2}$ concentration at the "Parzniewice" measuring station, in the analyzed period of 10 years there was no clear correlation between the reduction of equivalent emissions from power plants and changes in the concentration of $\mathrm{SO}_{2}$ and $\mathrm{NO}_{2}$ (table 3 , table 4).

Table 3. Changes in the emissions and concentration of air pollutants at "Lodz-Widzew" in 2007-2016

\begin{tabular}{|c|c|c|c|c|c|c|c|c|c|c|}
\hline \multirow{3}{*}{ Year } & \multicolumn{8}{|c|}{ Lodz-Widzew } & \multicolumn{2}{|c|}{ Veolia Energia Lodz SA } \\
\hline & \multicolumn{4}{|c|}{ Concentration $\left[\mu \mathrm{g} / \mathrm{m}^{3}\right]$} & \multicolumn{4}{|c|}{ Change from 2007 [\%] } & \multirow{2}{*}{$\begin{array}{l}\text { Equivalent } \\
\text { emission } \\
{[\mathrm{Mg} / \mathrm{yr}]}\end{array}$} & \multirow{2}{*}{$\begin{array}{l}\text { Change } \\
\text { from 2007 } \\
{[\%]}\end{array}$} \\
\hline & $\mathrm{NO}_{2}$ & NO & $\mathrm{SO}_{2}$ & $\mathbf{O}_{3}$ & $\mathrm{NO}_{2}$ & NO & $\mathrm{SO}_{2}$ & $\mathrm{O}_{3}$ & & \\
\hline 2007 & 16.4 & 3.2 & 15.8 & 54.7 & - & - & - & - & 18305.1 & - \\
\hline 2008 & 19.1 & 3.3 & 12.2 & 53.2 & $17 \%$ & $4 \%$ & $-23 \%$ & $-3 \%$ & 12822.4 & $-30 \%$ \\
\hline 2009 & 19.0 & 5.0 & 9.4 & 50.7 & $16 \%$ & $57 \%$ & $-41 \%$ & $-7 \%$ & 11890.7 & $-35 \%$ \\
\hline 2010 & 18.1 & 4.2 & 12.9 & 52.2 & $10 \%$ & $33 \%$ & $-18 \%$ & $-5 \%$ & 13061.5 & $-29 \%$ \\
\hline 2011 & 19.4 & 4.1 & 11.6 & 53.7 & $18 \%$ & $29 \%$ & $-26 \%$ & $-2 \%$ & 11236.6 & $-39 \%$ \\
\hline 2012 & 19.1 & 3.7 & 9.5 & 52.3 & $16 \%$ & $15 \%$ & $-40 \%$ & $-4 \%$ & 9952.5 & $-46 \%$ \\
\hline 2013 & 18.6 & 3.9 & 9.3 & 53.1 & $13 \%$ & $24 \%$ & $-41 \%$ & $-3 \%$ & 8302.5 & $-55 \%$ \\
\hline 2014 & 16.9 & 3.8 & 9.0 & 51.2 & $3 \%$ & $19 \%$ & $-43 \%$ & $-6 \%$ & 5302.1 & $-71 \%$ \\
\hline 2015 & 18.5 & 3.3 & 5.3 & 55.6 & $13 \%$ & $5 \%$ & $-67 \%$ & $2 \%$ & 6518.0 & $-64 \%$ \\
\hline 2016 & 18.3 & 3.4 & 4.0 & 51.1 & $12 \%$ & $8 \%$ & $-75 \%$ & $-7 \%$ & 4439.9 & $-76 \%$ \\
\hline
\end{tabular}

Source: Author's

Table 4. Changes in the emissions and concentration of air pollutants at "Parzniewice" in 2007-2016

\begin{tabular}{|c|c|c|c|c|c|c|c|c|c|c|}
\hline \multirow{3}{*}{ Year } & \multicolumn{8}{|c|}{ Parzniewice } & \multicolumn{2}{|c|}{ PGE GIEK Bełchatow } \\
\hline & \multicolumn{4}{|c|}{ Concentration $\left[\mu \mathrm{g} / \mathrm{m}^{3}\right]$} & \multicolumn{4}{|c|}{ Change from 2007 [\%] } & \multirow{2}{*}{$\begin{array}{l}\text { Equivalent } \\
\text { emission } \\
{[\mathrm{Mg} / \mathrm{yr}]}\end{array}$} & \multirow{2}{*}{$\begin{array}{l}\text { Change } \\
\text { from } 2007 \\
{[\%]}\end{array}$} \\
\hline & $\mathrm{NO}_{2}$ & NO & $\mathrm{SO}_{2}$ & $\mathbf{O}_{3}$ & $\mathrm{NO}_{2}$ & NO & $\mathrm{SO}_{2}$ & $\mathrm{O}_{3}$ & & \\
\hline 2007 & 14.3 & 2.4 & 9.8 & 57.3 & - & - & - & - & 114968.4 & - \\
\hline 2008 & 14.4 & 2.7 & 11.5 & 55.1 & $0 \%$ & $14 \%$ & $17 \%$ & $-4 \%$ & 83623.3 & $-27 \%$ \\
\hline 2009 & 14.1 & 2.8 & 8.9 & 52.8 & $-2 \%$ & $15 \%$ & $-9 \%$ & $-8 \%$ & 73230.9 & $-36 \%$ \\
\hline 2010 & 15.1 & 2.7 & 9.0 & 53.7 & $6 \%$ & $12 \%$ & $-8 \%$ & $-6 \%$ & 95304.4 & $-17 \%$ \\
\hline 2011 & 12.6 & 2.5 & 9.1 & 56.3 & $-12 \%$ & $2 \%$ & $-7 \%$ & $-2 \%$ & 100452.0 & $-13 \%$ \\
\hline 2012 & 12.9 & 2.3 & 10.0 & 56.5 & $-10 \%$ & $-4 \%$ & $2 \%$ & $-1 \%$ & 98761.6 & $-14 \%$ \\
\hline 2013 & 12.5 & 2.0 & 9.1 & 56.6 & $-13 \%$ & $-17 \%$ & $-7 \%$ & $-1 \%$ & 81780.8 & $-29 \%$ \\
\hline 2014 & 12.5 & 2.1 & 8.3 & 51.6 & $-13 \%$ & $-15 \%$ & $-15 \%$ & $-10 \%$ & 91315.6 & $-21 \%$ \\
\hline 2015 & 12.1 & 1.9 & 6.1 & 58.2 & $-16 \%$ & $-21 \%$ & $-38 \%$ & $2 \%$ & 92684.0 & $-19 \%$ \\
\hline 2016 & 13.2 & 1.7 & 4.0 & 59.8 & $-8 \%$ & $-29 \%$ & $-59 \%$ & $4 \%$ & 44547.4 & $-61 \%$ \\
\hline
\end{tabular}

Source: Author's 
For the comparison, changes in wind directions at analyzed points were calculated. Meteorological conditions were measured at "Lodz-Widzew", and at measuring station "Piotrkow Trybunalski", which is the nearest (around $19 \mathrm{~km}$ ) measuring station to "Parzniewice". The "EC-4" power plant is located at SE direction to "'Lodz-Widzew", and "PGE GIEK Belchatow" is located at WSW direction to "Parzniewice". However, at "LodzWidzew" dominated (13.4\%) wind direction W, and near to "Parzniewice", at "Piotrkow" measuring station, dominated (9.3\%) wind direction SW (fig. 6). Also, wind direction changed from year to year (table 5), which surely influenced concentration of air pollutants.

Lodz-Widzew, 2007-2016

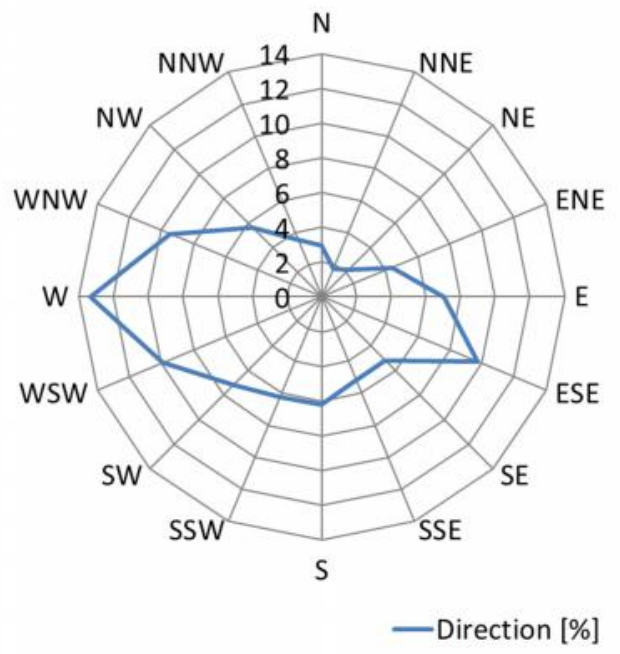

Parzniewice, 2007-2016

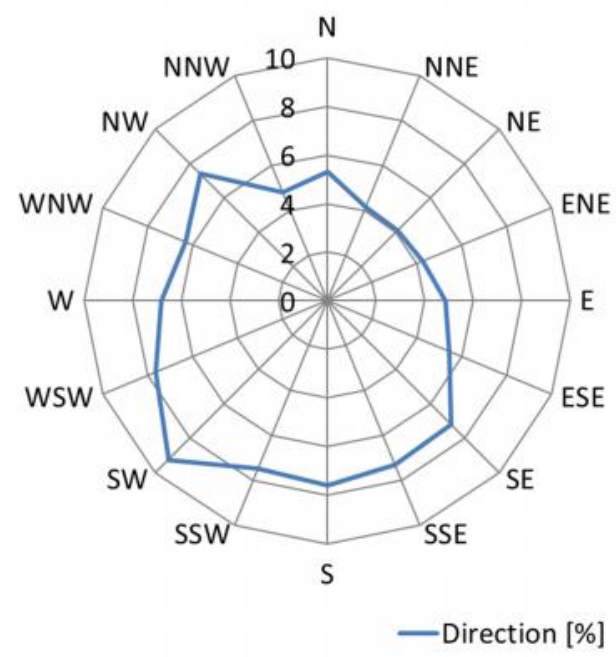

Fig. 6. Wind directions at "Lodz-Widzew" and near "Parzniewice" measuring stations in 2007-2016 Source: Author's

Table 5. Changes in the wind direction

\begin{tabular}{|c|c|c|c|c|}
\hline \multirow{3}{*}{ Year } & \multicolumn{4}{|c|}{ Wind direction [\%] } \\
\hline & \multicolumn{2}{|c|}{ Lodz-Widzew } & \multicolumn{2}{|c|}{ Parzniewice } \\
\hline & SE & $\begin{array}{l}\text { Change } \\
\text { from } 2007\end{array}$ & WSW & $\begin{array}{l}\text { Change } \\
\text { from } 2007\end{array}$ \\
\hline 2007 & 3.8 & - & 10.5 & - \\
\hline 2008 & 4.6 & +0.8 & 15.8 & +5.3 \\
\hline 2009 & 5.7 & +1.8 & 11.1 & +0.6 \\
\hline 2010 & 4.6 & +0.8 & 4.2 & -6.3 \\
\hline 2011 & 5.2 & +1.4 & 12.1 & +1.7 \\
\hline 2012 & 5.2 & +1.4 & 4.6 & -5.8 \\
\hline 2013 & 4.3 & +0.4 & 4.2 & -6.3 \\
\hline 2014 & 8.0 & +4.2 & 2.5 & -7.9 \\
\hline 2015 & 4.1 & +0.3 & 5.7 & -4.7 \\
\hline 2016 & 6.2 & +2.4 & 5.7 & -4.7 \\
\hline
\end{tabular}

Source: Author's

The relationships between the $\mathrm{NO}_{2}$ and $\mathrm{SO}_{2}$ concentrations at the "Lodz-Widzew" and "Parzniewice" measurement stations, and the respective power plants are shown in fig. 7 and fig 8. 


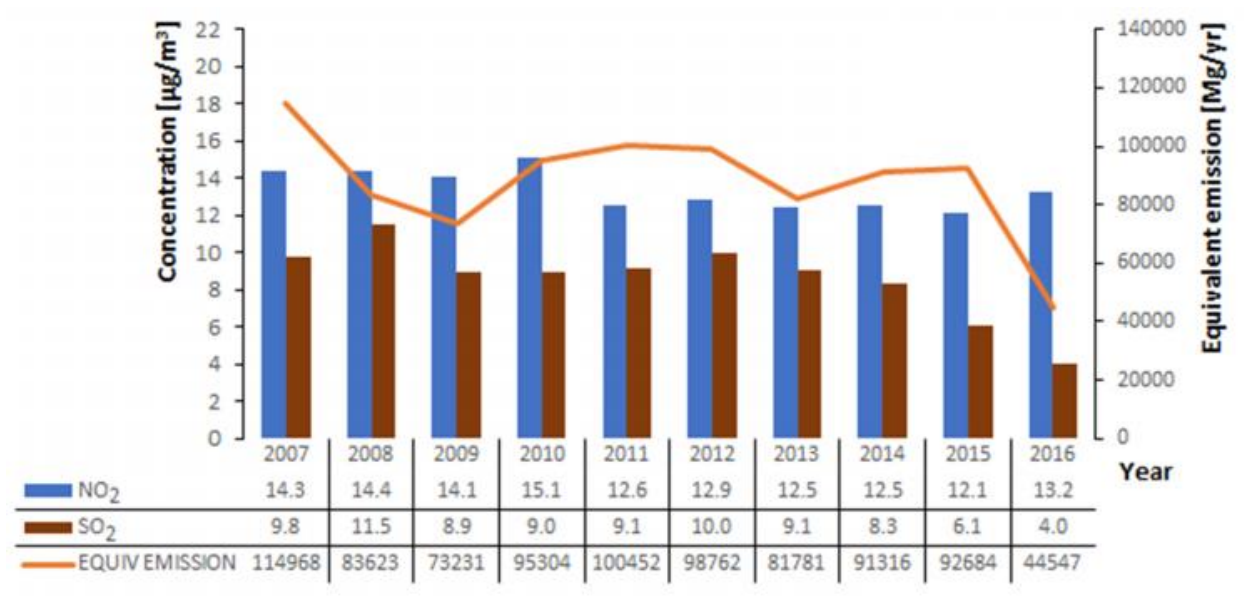

Fig. 7. Air pollutants concentrations at the "Lodz-Widzew" and equivalent emission of Veolia Energia Lodz Source: Author's



Fig. 8. Air pollutants concentrations at the "Parzniewice" and equivalent emission of PGE GIEK Belchatow Source: Author's

Analyzing the population density in poviats, in which measurement stations are located, i.e. indirectly also the number of people exposed to adverse air pollution, no dependence between $\mathrm{NO}_{2}, \mathrm{SO}_{2}$ and $\mathrm{O}_{3}$ concentration and the number of people in the analyzed areas was observed. The city of Lodz, which is a town poviat, where high and low density residential, industrial and service zones predominate, and where the "Lodz-Widzew" measuring station is located, is characterized by a large but decreasing value of population density (about $0.9 \%$ per year), Meanwhile, for 10 years the $\mathrm{NO}_{2}$ concentration increased by $12 \%$, and the $\mathrm{O}_{3}$ concentration decreased by $7 \%$ (fig. 9)

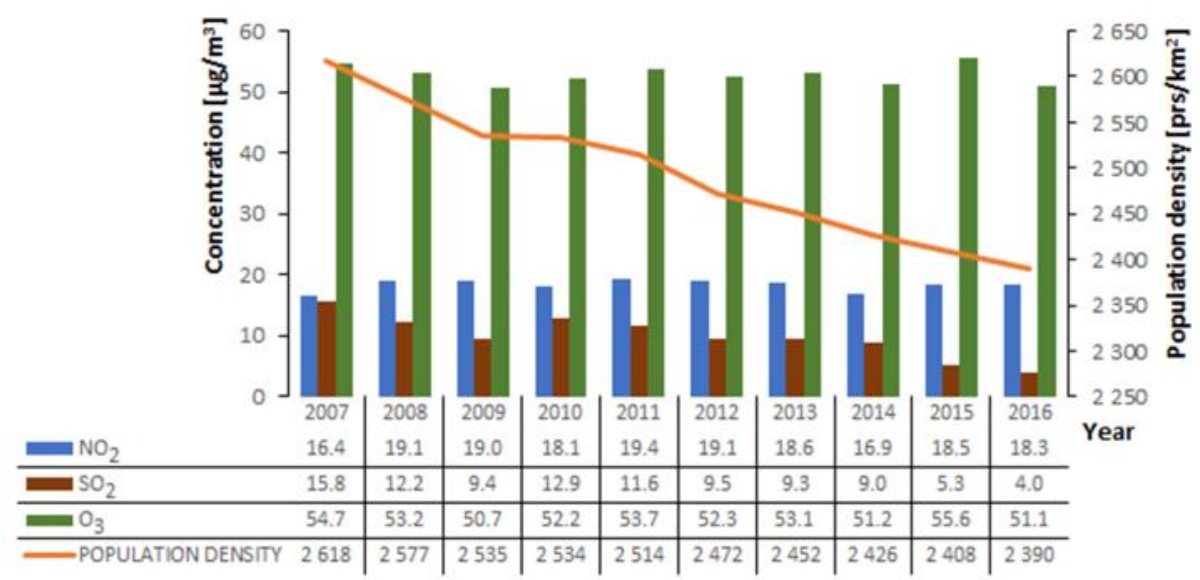

Fig. 9. Air pollutants concentrations at the "Lodz-Widzew" and the population density of Lodz city Source: Author's 
The Piotrkow poviat in which rural and agricultural areas predominate, and where the "Parzniewice" measuring station is located, is characterized by a small but increasing value of population density (about $0.1 \%$ per year), while in 10 years the $\mathrm{NO}_{2}$ concentration decreased by $8 \%$, and $\mathrm{O}_{3}$ concentration increased by $4 \%$ (fig 10 ).

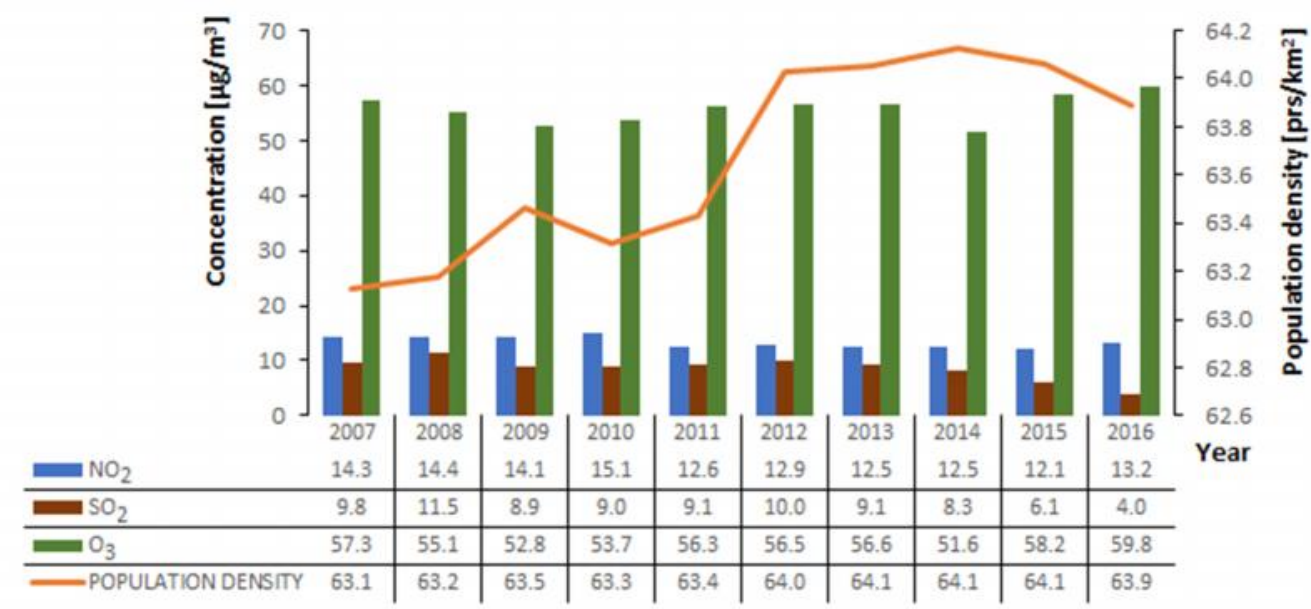

Fig. 10. Air pollutants concentrations at the "Parzniewice" and the population density of Piotrkow poviat Source: Author's

\section{Conclusions}

As a result of the analysis carried out in selected locations over a period of 10 years (between 2007 and 2016), small changes (between $-8 \%$ and $+12 \%$ ) of $\mathrm{NO}_{2}$ and $\mathrm{O}_{3}$ were found in urban and agricultural areas. However, when comparing emissions from local power plants and combined heat and power plants with the concentration of pollutants in selected metering stations, no clear correlation was found between the reduction of equivalent emissions from power plants and changes in the $\mathrm{SO}_{2}$ and $\mathrm{NO}_{2}$ concentration in the air. On the other hand, change in wind directions during 2007-2016 period could influenced concentration of air pollutants. Especially that "Lodz-Widzew" measuring station was not located in the dominant wind direction from "EC-4" power plant. The 10-year distribution of pollutant concentration was different for both locations. The levels of air pollutants in urban and rural areas differed by approximately $\pm 13-35 \%$ for $\mathrm{NO}_{2}$, and $\pm 16-38 \%$ for $\mathrm{SO}_{2}$, and $\pm 5-17 \%$ for $\mathrm{O}_{3}$. The concentrations of $\mathrm{NO}_{2}$ and $\mathrm{SO}_{2}$ in the air were higher in urban areas by $13-35 \%$ and $0-38 \%$ respectively. However, it was observed that in 2012 and 2015 the $\mathrm{SO}_{2}$ concentration in the agricultural area was higher by $6 \%$ and $16 \%$ respectively. In contrast, the $\mathrm{NO}_{2}$ and $\mathrm{SO}_{2}$ concentration limit values were not exceeded for both urban and agricultural locations, except for the winter of 2007/2008 at the "Lodz-Widzew" station, where the average $\mathrm{SO}_{2}$ concentration exceeded $20 \mu \mathrm{g} / \mathrm{m}^{3}$, which is a criterion for plant protection. This means that, considering the protection of human health, air quality was generally good in the analyzed period in both selected locations. In addition, $\mathrm{NO}_{2}$ and $\mathrm{SO}_{2}$ concentrations at the selected urban and rural locations did not differ significantly.

On the other hand, the concentration of $\mathrm{O}_{3}$ was always higher (by 1-17\%) in the agricultural area, although there was a lower concentration of $\mathrm{NO}_{2}$ (which contributes to the formation of tropospheric ozone). And the occurrence of ground-level ozone is a disadvantage for the economy of the agricultural area due to the negative impact on plant vegetation, especially since the exceedance of the recommended concentration of $\mathrm{O}_{3}$ in the air occurred mostly from April to August, i.e. in the summer. It should be remembered that ground-level ozone is formed as a result of photochemical transformation of the oxidation of nitrogen oxides in the presence of $\mathrm{CO}, \mathrm{CH}_{4}$ and non-methane volatile organic compounds (NMVOCs). Therefore, the main sources of ozone pollution are energy, transport $\left(\mathrm{NO}_{\mathrm{x}}\right)$, industry (NMVOCs), communal housing (CO), mining industry, fuel distribution, agriculture and landfills $\left(\mathrm{CH}_{4}\right)$. Therefore, it is necessary to take a closer look at the processes of ground-level ozone formation in agricultural areas, especially in relation to the concentration of nitrogen oxides, as well as the impact of sources of air pollutants other than power stations [29]. For this reason, it seems that the next step in the protection of vegetation should be the analysis of the location of pollution sources in relation to agricultural and forest areas. At the same time, according to Guereirro et al. [30], differences in $\mathrm{O}_{3}$ concentration in urban and agricultural areas result from the removal of ozone from the atmosphere by $\mathrm{NO}$ and thus from the formation of $\mathrm{NO}_{2}$, which seems to be in line with the results of this analysis. However, according to this assumption, the $\mathrm{NO}_{2}$ concentration should increase with decreasing NO 
and $\mathrm{O}_{3}$ concentrations. However, in the agricultural area $\mathrm{NO}_{2}$ decreased by $8 \%$ and $\mathrm{NO}$ by $29 \%$ (with $\mathrm{NO} / \mathrm{NO}_{2}$ ratio decrease by $23 \%$ ), while the $\mathrm{O}_{3}$ concentration increased by $4 \%$. And in the city, the $\mathrm{NO}_{2}$ concentration increased by $12 \%$, and $\mathrm{NO}$ by $8 \%$ (with $\mathrm{NO} / \mathrm{NO}_{2}$ ratio decrease by $3 \%$ ), while the $\mathrm{O}_{3}$ concentration decreased by $7 \%$.

In the analysis no relationship was observed between changes in $\mathrm{NO}_{2}, \mathrm{SO}_{2}$ and $\mathrm{O}_{3}$ concentrations in the air, and the average density of population in the surrounding areas, both in the city and in the countryside. Hypothetically, the change in the number of inhabitants living in a given area should change the emission associated to vehicles (linear sources of emission) and residential boilers (area sources of emission) or the trend of emission of pollutants [31-32], but this analysis has not shown it. Recognized lack of correlation between the growth and fall of population density and the concentration of pollutants indirectly indicates the high importance of emission from point sources in the average concentration of pollutants in selected areas.

Tightening the air protection criteria, inter alia as a result of the implementation of EU Directives [19-20], allowed to significantly reduce the emission of $\mathrm{SO}_{2}$ air pollution from point sources of the power industry, which resulted in a drop in the concentration of this pollutant in the air in selected urban and agricultural areas. The analyzed power plants reduced emission by $61-76 \%$ in last 10 years. Still, the cost of modernization of Polish power plants is estimated to around 3 billion USD [33]. Also, the PGE power producer is planning to spend up to around 470 million USD on emission reduction in line with European Union regulations [33]. If a current trend in power plant emission reduction will sustain, there can be another decrease of $60-80 \%$ of equivalent emission in further 10 years.

As to the current situation, the threat to urban and rural population and the threat to vegetation, caused by the presence of $\mathrm{SO}_{2}$ in the air, and the possibility of acid rainfall, decreased. However, taking into account the criterion of permissible concentration of ground-level ozone and nitrogen dioxide, it can be concluded that the air quality index can usually be considered as "good". Unfortunately, during the whole decade, the levels of concentrations of these harmful gases in the air have not significantly improved, which in combination with exceedances of $\mathrm{O}_{3}$ concentrations limit values in subsequent years may expose the vegetation during the growing season and people living in these areas to harmful effects of $\mathrm{NO}_{2}$ and $\mathrm{O}_{3}$.

\section{References}

[1] M. L. Williams, 6 - Patterns of Air Pollution in Developed Countries, Air Pollution and Health (1999) 83-104 https://doi.org/10.1016/B978-012352335-8/50081-8

[2] WHO, 2000. Air Quality Guidelines for Europe, World Health Organization, Regional Office for Europe, WHO Regional Publications, European Series, No. 91, Copenhagen, 2000

[3] R. Cichowicz, G. Wielgosiński, W. Fetter, Dispersion of atmospheric air pollution in summer and winter season, Environmental Monitoring and Assessment, (2017) 189-605 https://doi.org/10.1007/s10661-0176319-2

[4] WHO, 2013. Review of Evidence on Health Aspects of Air Pollution - REVIHAAP Project. Technical Report, World Health Organization, Regional Office for Europe, Copenhagen, 2000.

[5] U. Ackermann-Liebrich, R. Rapp, 25 - Epidemiological Effects of Oxides of Nitrogen, Especially NO2, Air Pollution and Health (1999) 561-584, https://doi.org/10.1016/B978-012352335-8/50100-9

[6] R. B. Schlesinger, 26 - Toxicology of Sulfur Oxides, Air Pollution and Health 1999, Pages 585-602, https://doi.org/10.1016/B978-012352335-8/50101-0

[7] S. Sudalma,P. Purwantoa,L. W. Santosod, The Effect of SO2 and NO2 from Transportation and Stationary Emissions Sources to SO42- and NO3- in Rain Water in Semarang, Procedia Environmental Sciences Volume (23) (2015) 247-252 https://doi.org/10.1016/j.proenv.2015.01.037

[8] R. Mmuzika, R. Pguyette, T. Zielonka, A. Mliebhold, The influence of O3, NO2 and SO2 on growth of Picea abies and Fagus sylvatica in the Carpathian Mountains, Environmental Pollution 130 (1) (2004) 65-71 https://doi.org/10.1016/j.envpol.2003.10.021 
[9] G. D. Thurston, K. Ito, 22 - Epidemiological Studies of Ozone Exposure Effects, Air Pollution and Health (1999) 485-510 https://doi.org/10.1016/B978-012352335-8/50097-1

[10] Environmental Protection Inspection, National Mosaic Report. State of the Environment in the years 20002007 (Inspekcja Ochrony Środowiska, Krajowy Raport Mozaikowy. Stan Środowiska w latach 200-2007), Library of Environmental Monitoring, Warsaw 2010 http://www.gios.gov.pl/stansrodowiska/upload/file/pdf/download/krajowy_raport_mozaik_n.pdf

[11] K.N. Priftis, M. B. Anthracopoulos, A. G. Paliatsos, G. Tzavelas, A. Nikolaou-Papanagiotou, P. Douridas, P.Nicolaidou, E. Mantzouranis, Different effects of urban and rural environments in the respiratory status of Greek schoolchildren, Respiratory Medicine 101 (1) (2007) 98-106 https://doi.org/10.1016/j.rmed.2006.04.008

[12] H. Strosnider, C. Kennedy, M. Monti, F. Yip, Rural and Urban Differences in Air Quality, 2008-2012, and Community Drinking Water Quality, 2010-2015 - United States, Surveillance Summaries 66 (13) (2017) 1-10 http://dx.doi.org/10.15585/mmwr.ss6613a1

[13] S. Gulia, S.M. S. Nagendra, M. Khare, I. Khanna, Urban air quality management-A review, Atmospheric Pollution Research 6 (2) (2015) 286-304 https://doi.org/10.5094/APR.2015.033

[14] G. Wielgosiński, J. Czerwińska, O. Namiecińska, R. Cichowicz, Smog episodes in the Lodz agglomeration in the years 2014-17, E3S Web of Conferences 28 (01039) (2018) https://doi.org/10.1051/e3sconf/20182801039

[15] C. Holman, 8 - Sources of Air Pollution, Air Pollution and Health (1999) 115-148 https://doi.org/10.1016/B978-012352335-8/50083-1

[16] D. M. Whitacre, Reviews of Environmental Contamination and Toxicology, Springer Science+Business Media, New York 2013

[17] R. Cichowicz, G. Wielgosiński, W. Fetter, Impact of pollutants emitted by large industrial plants on the quality of atmospheric air, Polish Journal of Environmental Studies 26 (5A) (2017) 8-13

[18] R. Cichowicz, Spatial distribution of pollutants in the area of the former CHP plant, E3S Web of Conferences 28 (01007) 2018 https://doi.org/10.1051/e3sconf/20182801007.

[19] EU, 2008. Directive 2008/50/EC of the European Parliament and of the Council of 21 May 2008 on Ambient Air Quality and Cleaner Air for Europe, OJ L 152, 11.6.2008, pp. 1-44.

[20] EU, 2010. Directive 2010/75/EU of the European Parliament and of the Council of 24 November 2010 on industrial emissions (integrated pollution prevention and control) OJ L 334, 17.12.2010, p. 17-119

[21] PL, 2001. The Act Of 27 April 2001, The Environmental Protection Law (Ustawa z dnia 27 kwietnia 2001 r. Prawo ochrony środowiska), Dz.U. 2001 nr 62 poz. 627

[22] PL, 2012. Regulation of the Minister of the Environment of 11 September 2012 on air protection programs and short-term action plans (Rozporządzenie Ministra Środowiska z dnia 11 września 2012 r. w sprawie programów ochrony powietrza oraz planów działań krótkoterminowych), Dz.U. 2012 poz. 1028.

[23] http://www.wios.lodz.pl/Roczne_oceny_jakosci_powietrza,141

[24] WHO, 2006. Air Quality Guidelines. Global Update 2005. Particulate Matter, Ozone, Nitrogen dioxide and Sulfur dioxide. World Health Organization, Regional Office for Europe, Copenhagen, 2005.

[25] http://www.wios.lodz.pl/Lodz-Widzew,211,2

[26] https://www.google.pl/maps 
[27] http://www.wios.lodz.pl/Parzniewice,211,6

[28] PL, 2012. Regulation of the Minister of the Environment of 24 August 2012 on the levels of certain substances in the air (Rozporządzenie Ministra Środowiska z dnia 24 sierpnia 2012 r. w sprawie poziomów niektórych substancji w powietrzu), Dz.U. 2012 poz. 1031

[29] R. C. Wilson, Z. L. Fleming, P. S. Monks, G. Clain, S. Henne, I. B. Konovalov, S. Szopa, L. Menut, Have primary emission reduction measures reduced ozone across Europe? An analysis of European rural background ozone trends 1996-2005, Atmos. Chem. Phys. 12 (2012) 437-454 http://dx.doi.org/10.5194/acp-12-437-2012

[30] C. B.B. Guerreiro, V. Foltescu, F. de Leeuw, Air quality status and trends in Europe, Atmospheric Environment 98 (2014) 376-384 http://dx.doi.org/10.1016/j.atmosenv.2014.09.017

[31] H. Shen, Y. Chena, A. G. Russell, Y. Hu, G. Shen, H. Yu, L. R.F. Henneman, M. Rua, Ye Huang, Q. Zhong, Y. Chen, Y. Li, Y. Zou, Impacts of rural worker migration on ambient air quality and health in China: From the perspective of upgrading residential energy consumption, Environment International (2018) https://doi.org/10.1016/j.envint.2017.11.033

[32] S.P. Bhoyar, S. Dusad, R. Shrivastava, S. Sidharth Mishra, N. Gupta, A. B. Rao, Understanding the impact of lifestyle on individual carbonfootprint, Procedia - Social and Behavioral Sciences 133 ( 2014) 47 - 60 https://doi: 10.1016/j.sbspro.2014.04.168

[33] https://www.reuters.com/article/us-pge-polska-investment-idUSKCN10L12Q 